\title{
MENINGKATKAN KUALITAS PEMBELAJARAN MATEMATIKA TENTANG NILAI TEMPAT
}

\author{
F.T. Munthe
}

\begin{abstract}
This class action research aims at overcoming the problems in learning place value in mathematics and improving the student's learning achievement. This action research was conducted in grade 3 of Government Primacy School, Jati 03 (Morning), East Jakarta. The research model adopted Kemmis and Mc Taggart's with four steps (Planning, Implementation, Observation, and Reflection). Within three cycles, it was discovered the effectiveness of teaching aids in improving the student's learning achievement in studying place value in mathematics.
\end{abstract}

Keywords: place value, learning achievement, teaching aids.

\section{PENDAHULUAN}

\section{Latar Belakang Masalah}

Rendahnya kualitas pembelajaran akan diikuti dengan hasil belajar yang rendah pula. Ini terbukti dengan hasil belajar Matematika tentang materi nilai tempat pada siswa kelas III Sekolah Dasar Negeri (SDN) Jati 03 Pagi sangat memprihatinkan.

Hasil evaluasi belajar Matematika tentang nilai tempat yang memperoleh nilai enam sampai dengan delapan hanya $20 \%$, sisanya $80 \%$ memperoleh nilai di bawah enam. Telah banyak usaha yang dilakukan tetapi hasilnya belum mencapai harapan. Padahal target keberhasilan pelaksanaan kurikulum di SDN Jati 03 Pagi adalah 75\%.

Masalah hasil belajar ini jika dibiarkan akan menimbulkan dampak psikologis, yaitu siswa akan tidak berminat belajar Matematika atau tidak senang terhadap pelajaran Matematika. Selanjutnya kemudian siswa tidak senang terhadap gurunya dan pada gilirannya tidak mau lagi sekolah atau drop out. Hal ini akan bertentangan dengan tujuan pendidikan, yaitu tercapainya Sumber Daya Manusia (SDM) yang handal untuk membangun bangsa Indonesia yang kita cintai.

Dampak lainnya adalah dampak akademik yaitu jika pokok bahasan nilai tempat tidak dikuasai maka siswa akan menghadapi kesulitan dalam memberi nama suatu bilangan jika diketahui lambang bilangannya. Demikian juga sebaliknya, siswa menghadapi kesulitan menuliskan lambang bilangan jika diketahui lambang suatu bilangan. Siswa juga akan menghadapi kesulitan dalam menjumlah, mengurangkan, mengalikan, dan membagi jika tidak menguasai nilai tempat suatu bilangan.
Menurut petunjuk pelajaran berhitung di kelas 1, 2, dan 3 pada tahun 1992/1993 (1994), prinsip pembelajaran berhitung di SD di antaranya adalah penggunaan benda-benda konkret untuk membantu pemahaman siswa terhadap pengertian dalam berhitung. Pembelajaran berhitung hendaknya diusahakan melalui penyajian untuk menghindarkan terjadinya tekanan atau ketegangan pada diri siswa. Latihan sangat penting untuk memantapkan pengertian dan keterampilan karena pembelajaran berhitung yang dilandasi pengertian akan mengakibatkan daya ingat dan daya transfer yang lebih besar.

Petunjuk pembelajaran berhitung tersebut direkomendasikan juga oleh Jean Piaget (Suparno, 2000) mengatakan bahwa usia 7-11 tahun, dalam ini siswa kelas III SD, termasuk masih dalam tahap kemampuan berpikir operasi konkret. Oleh karena itu, dalam pembelajaran Matematika atau berhitung penggunaan alat bantu seperti benda-benda konkret adalah sangat efektif untuk memudahkan siswa memahami pembelajaran yang dilaksanakan oleh guru.

Dari uraian di atas mengenai pendayagunaan alat bantu dalam pembelajaran Matematika yang dapat memudahkan siswa dalam memahami pengertian materi nilai tempat sehingga menyebabkan kualitas pembelajaran meningkat maka rumusan masalah dalam penelitian yang dilakukan ini adalah "Bagaimana caranya meningkatkan kualitas pembelajaran Matematika dalam nilai tempat dengan mengefektifkan alat bantu di kelas III SDN Jati 03 Pagi, Jakarta Timur, DKI Jakarta". Untuk memahami berbagai konsep teoretis yang mendukung permasalahan tersebut maka akan dibahas tentang beberapa teori yang melandasi permasalahan di atas. 


\section{KAJIAN TEORETIS}

Kualitas Pembelajaran Matematika tentang Nilai Tempat

1. Pengertian kualitas

Menurut Sutikno (2007) kualitas pembelajaran dapat dicapai oleh seorang guru yang kreatif, profesional, menyenangkan, mendisiplinkan peserta didik dengan kasih sayang, membangkitkan motivasi belajar, dan melibatkan masyarakat dalam pembelajaran.

Turrney dalam Mulyasa (2005:175) mengemukakan, untuk meningkatkan kualitas pembelajaran diperlukan delapan keterampilan membelajarkan antara lain: (1) keterampilan bertanya, (2) memberi penguatan, (3) mengadakan variasi (kreatif), (4) menjelaskan, (5) membuka dan menutup pelajaran, (6) membimbing diskusi dalam kelompok kecil, (7) mengelola kelas, serta (8) membelajarkan kelompok kecil dan perorangan.

Menurut Kurikulum Tingkat Satuan Pendidikan (KTSP), mutu pembelajaran itu diukur dari tiga aspek yaitu kognitif, afektif, dan psikomotor. Penguasaan kognitif diukur melalui hasil evaluasi belajar, aspek afektif diukur melalui angket, dan aspek psikomotor diukur dari tes perbuatan.

Secara umum kualitas pembelajaran dapat diamati melalui pencapaian hasil belajar yang ditempuh oleh siswa. Biasanya untuk mengetahui keberhasilan pembelajaran, guru akan memberikan siswa tes. Jika tes yang diberikan berhasil mencapai target yang telah ditentukan oleh guru maka pembelajaran dikatakan berhasil.

\section{Pengertian pembelajaran}

Menurut Dimyati dan Mudijono (2006) pembelajaran dapat diartikan sebagai kegiatan yang ditujukan untuk membelajarkan siswa. Kualitas pembelajaran adalah mutu dari usaha-usaha guru untuk membelajarkan siswa sehingga tercapainya tujuan pembelajaran.

3. Pengertian kualitas pembelajaran Matematika

Kualitas pembelajaran Matematika akan terlihat pada target pencapaian hasil belajar. Menurut KTSP yang dimiliki oleh SDN Jati 03 Pagi, target pencapaian hasil belajar untuk mata pelajaran Matematika adalah $75 \%$ dari jumlah siswa berhasil mencapai nilai enam ke atas. Menurut Angkowo dan Kosasih (2007), kualitas pembelajar adalah tinggi rendahnya atau efektif tidaknya proses pembelajaran yang diupayakan pendidik dalam mencapai tujuan.

Tolak ukur efektif tidaknya pembelajaran dapat diamati melalui hasil evaluasi belajar yang dicapai oleh siswa untuk setiap indikator. Untuk mencapai hasil belajar yang diinginkan maka pembelajaran harus dapat meningkatkan faktor-faktor pengaruh yang menyenangkan anak, khususnya pada pelajaran Matematika.

\section{Alat Bantu Belajar Membelajarkan Mematika (Teaching Aid for Mathematica Instructional Aid)}

Menurut National Council of Teachers of Mathematics (NCTM) "an instructional aid in mathematics is viewed as any obyect of equipment model, device, instrument, publication, picture, chart or any facility that serves the purpose of enhancing or effecting the learning of mathematics" (alat bantu membelajarkan adalah setiap model, perlengkapan, peralatan, instrumen, publikasi, gambar, peta atau setiap fasilitas yang dapat meningkatkan keberhasilan pembelajaran mata pelajaran Matematika).

Menurut Gagne dan Reiser dalam Sumantri, dkk. (1999) media pendidikan atau pembelajaran adalah sebagai alat-alat fisik di mana pesan-pesan instruksional dikomunikasikan. Dengan demikian maka seorang guru, buku cetak, pertunjukan film atau tape recorder, dan peralatan fisik lainnya yang dapat mengkomunikasikan pesan instruksional dianggap sebagai media pembelajaran.

Dari hasil uraian beberapa pendapat maka istilah alat bantu dalam judul penelitian ini adalah segala sesuatu yang digunakan, baik hardware atau alat perantara, yang tujuan atau fungsinya memudahkan siswa atau peserta didik memahami isi dan tujuan pelajaran sehingga hasil belajar meningkat.

\section{Karakteristik Siswa SD}

Dari aliran psikologi kognitif teori Piaget tampak lebih banyak digunakan dalam praktik pendidikan atau proses pembelajaran meskipun teori ini bukan teori membelajarkan. Menurut William C. Crain yang ditulis oleh Paimin (2007) adalah benar bahwa belajar tidak harus bepusat pada guru atau tenaga pendidikan, tetapi anak harus lebih aktif. Oleh karena itu, siswa harus dibimbing agar aktif menemukan sesuatu yang dipelajarinya. Konsekuensinya materi yang diberikan pun harus menarik minat belajar siswa sehingga mereka asyik dan terlibat dalam proses pembelajaran.

Teori Piaget mengatakan bahwa kemampuan anak berpikir akan lebih cepat dengan menggunakan benda-benda yang konkret(Horn, 1993). Contoh untuk menjelaskan penjumlahan 2+3 akan sangat cepat dengan menggunakan buah jeruk atau benda apa saja yang biasa dia lihat. Misalnya, dua buah apel ditambah tiga buah apel akan didapat lima buah apel yang dapat dihitungnya sendiri. 
Penyajian materi pelajaran harus lebih mementingkan pemahaman terhadap proses terbentuknya konsep daripada hasil akhir. Menurut teori Brownell dalam Souviney (1993:83) belajar Matematika harus merupakan belajar bermakna dan juga belajar pengertian. Artinya, Matematika dipelajari dan menghasilkan suatu perubahan baik dari kognitif, afektif maupun psikomotor dan juga proses pembelajarannya mengandung suatu pengertian yang dapat diterapkan dalam kehidupan sehari-hari.

\section{Kerangka Berpikir dan Pengajuan Hipotesis}

Alat bantu dapat membantu siswa untuk mudah memahami konsep dalam pembelajaran. Penggunaan alat bantu tentang pembelajaran Matematika dalam nilai tempat dapat meningkatkan kualitas pembelajaran. Dari kerangka berpikir tersebut dibangun suatu hipotesis tindakan yaitu semakin efektif penggunaan alat bantu dalam pembelajaran Matematika tentang nilai tempat semakin tinggi kualitas pembelajaran.

\section{METODOLOGI PENELITIAN}

\section{Tempat dan waktu Penelitian}

Penelitian ini dilakukan di kelas III SDN Jati 03 Pagi, yang beralamat di jalan Taman Pulo Asem Utara, Kecamatan Pulogadung, Kotamadya Jakarta Timur.

Waktu penelitian dilaksanakan pada semester I tahun pelajaran 2007-2008, yaitu pada bulan Agustus 2007 dan berakhir bulan November 2007.

\section{Metode Penelitan}

Jenis penelitian ini adalah tindakan (action reaserch). Penelitian tindakan merupakan penelitian yang bertujuan untuk memperbaiki efektivitas dan efisiensi praktik pendidikan. Menurut Sanford dalam Tim Dosen PTK (2006:5), penelitian tindakan merupakan suatu kegiatan siklus yang bersifat menyeluruh, yang terdiri dari analisis penemuan fakta, tambahan, dan evaluasi.

Selain itu, menurut Kemmis (Tim Dosen PTK, 2006:6) penelitian tindakan merupakan sebuah inquiry yang bersifat mandiri yang dilakukan oleh partisipan dalam situasi sosial termasuk kependidikan dengan maksud untuk meningkatkan kemantapan rasionalitas dari:

1. praktik sosial maupun kependidikan,

2. pemahaman terhadap praktik tersebut, dan

3. situasi pelaksanaan praktik pembelajaran.

Berdasarkan definisi yang dikemukakan oleh Sanford dan Kemmis di atas maka diperoleh suatu batasan tentang penelitian tindakan. Penelitian tindakan merupakan suatu proses investigasi terkendali yang berdaur ulang dan bersifat refleksi terhadap sistem, cara kerja, proses, isi kompetensi atau situasi.

Mengingat penelitian ini dilaksanakan di dalam kelas maka metode yang digunakan dalam penelitian ini adalah metode Classroom Action Research atau Penelitian Tindakan Kelas (PTK). Hopkins (Wiraatmadja, 2005:11) mengatakan, penelitian tindakan kelas adalah penelitian yang mengkombinasikan prosedur penelitian dengan tindakan substantif; suatu tindakan yang dilakukan dalam disiplin inquiry, atau suatu usaha seseorang untuk memahami apa yang sedang terjadi, sambil terus melakukan proses perbaikan dan perubahan.

\section{Hasil Intervensi Tindakan yang Diharapkan}

Keberhasilan dari setiap tindakan yang dilaksanakan dalam pembelajaran Matematika di kelas III dengan mengefektifkan alat bantu didasarkan kepada teori Mastery Learning atau belajar tuntas yang menyebutkan bahwa siswa diharapkan dapat mencapai sekurang-kurangnya $75 \%$ dari tujuan pembelajaran yang ditentukan (Arikunto, 1996). Keberhasilan dari setiap tindakan ini juga ditentukan oleh standar ketuntasan belajar yang ada pada SDN Jati 03 Pagi, yaitu siswa mencapai keberhasilan sekurang-kurangnya 75\% dari tujuan pembelajaran.

Pencapaian keberhasilan dari setiap tindakan yang dilaksanakan dapat dillihat dari hasil rata-rata observasi yang dilakukan oleh pengamat pada saat guru melakukan pembelajaran Matematika tentang nilai tempat.

Pelaksanaan pembelajaran Matematika dapat terlihat melalui:

1. aktivitas guru dalam pelaksanaan pengefektifan alat bantu meningkat dalam setiap siklusnya dan berada dalam rentangan baik (75\% dari butir pada instrumen yang dilakukan guru),

2. aktivitas siswa yang tergambar dalam suasana kelas dalam pembelajaran Matematika dengan mengefektifkan alat bantu meningkat dalam setiap siklusnya dan berada dalam rentangan (75\% jumlah siswa di kelas melakukan aktivitas pada butir instrumen), dan

3. hasil belajar atau prestasi belajar siswa meningkat pada setiap siklusnya dan mencapai nilai minimum 65.

\section{Sumber Data}

1. Data

Penelitian ini merupakan penelitian tindakan yang dilaksanakan untuk mengetahui peningkatan kualitas pembelajaran Matematika tentang nilai tempat dengan mengefektifkan alat bantu. Data penelitian 
terdiri dari: (a) data penelitian tindakan (action) dan (b) data hasil penelitian (research).

2. Sumber data

Sumber data dalam penelitian ini terbagi menjadi dua, yaitu sumber data pemantau tindakan dan sumber data penelitian. Sumber data pemantau tindakan adalah sumber data yang melihat proses aktivitas belajar Matematika kelas III SD dengan mengefektifkan alat bantu sedangkan sumber data penelitian yaitu siswa kelas III SDN Jati 03, guru, dan kolaborator.

\section{HASIL PENELITIAN}

\section{Siklus I}

1. Hasil tindakan penelitian

Berdasarkan tindakan penelitian siklus 1 dalam proses pembelajaran Matematika tentang nilai tempat dengan mengefektifkan alat bantu di kelas III maka hasil yang didapat untuk rata-rata hasil tes evaluasi belajar siswa adalah 59 dan pencapaian nilai enam sampai dengan sepuluh baru mencapai $50 \%$.

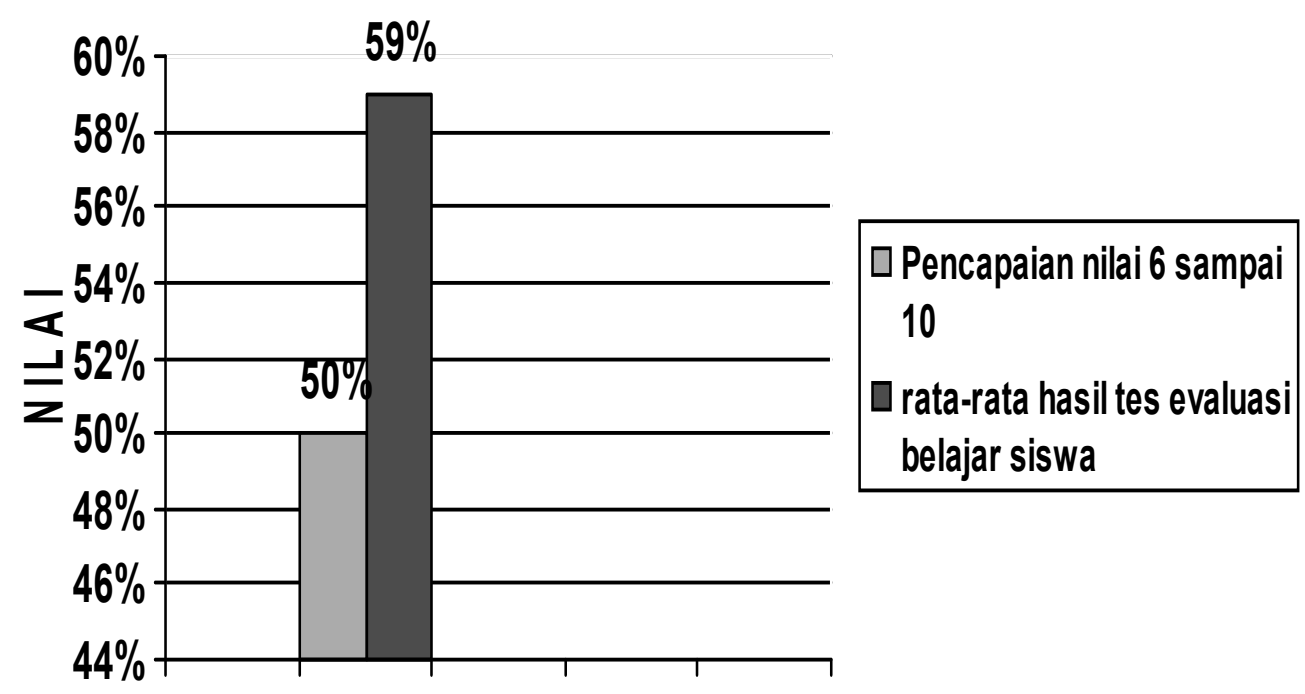

Gambar 1. Siklus I

2. Hasil pengamatan tindakan

Dari hasil pengamatan tindakan yang dilakukan oleh pengamat terhadap pelaksanaan tindakan pelajaran yang dilaksanakan oleh peneliti pada siklus I, diperoleh rata-rata persentase terhadap observasi sikap guru saat membelajarkan dan observasi terhadap suasana kelas yang di dalamnya tergambar aktivitas siswa saat pembelajaran sebesar $60 \%$. Berikut digambarkan mengenai pengamatan tindakan.

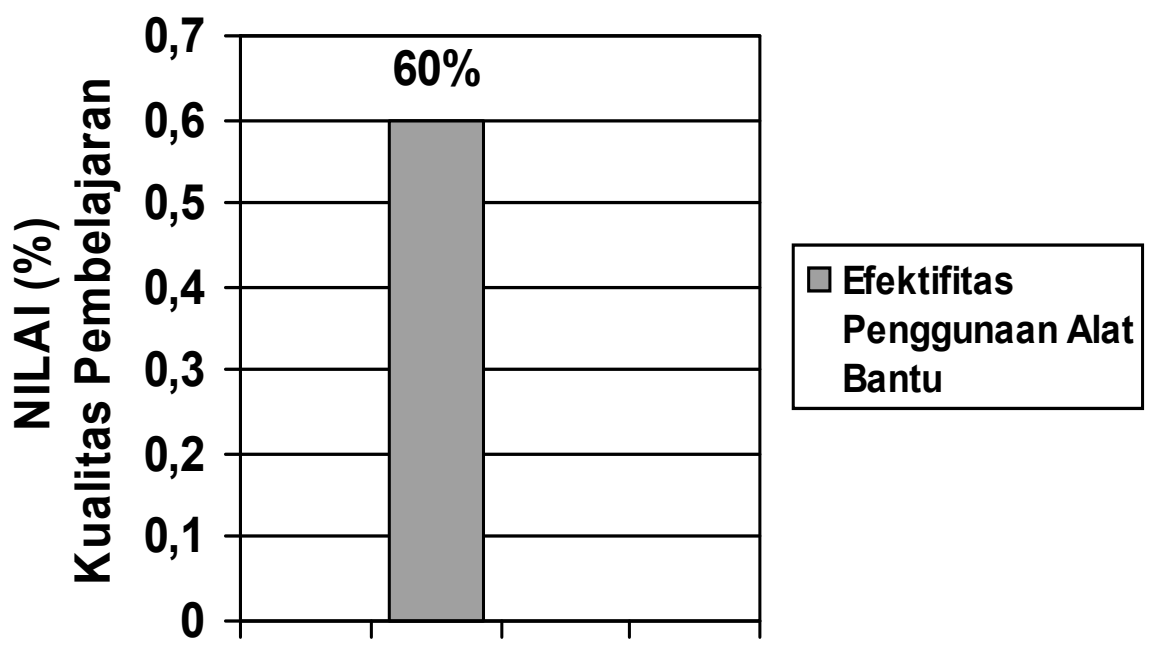

Efektifitas Penggunaan Alat Bantu

Gambar 2. Pengamatan tindakan siklus I 


\section{Refleksi tindakan}

Hasil intervensi tindakan yang sudah dilaksanakan oleh peneliti dalam melakukan tindakan pembelajaran tentang nilai tempat dengan mengefektifkan alat bantu di kelas III memperoleh hasil rata-rata nilai 59 dan pencapaian nilai enam sampai dengan sepuluh baru mencapai 50\% dan 60\%. Untuk proses pembelajaran yang meliputi aktivitas guru dan suasana kelas, yang menggambarkan aktivitas siswa serta membandingkan catatan lapangan mengenai kelebihan dan kekurangan dalam proses pem-belajaran siklus I, ditemukan sikap guru yang terlalu cepat membantu, siswa agak tenang dalam melakukan aktivitas pembelajaran, dan kurang memberikan kesempatan pada siswa untuk bereksplorasi menemukan konsep juga memperbaiki kesalahan. Selain itu, belum seluruh siswa mendengarkan saat orang lain berbicara, mandiri dalam melakukan aktivitas, dan kurangnya penguatan dari guru. Saat pembelajaran juga terlihat ketidakpuasan siswa dalam menemukan konsep karena sikap guru yang kurang terbuka. Selain itu, berdasarkan catatan lapangan dan diskusi dengan pengamat terlihat kondisi siswa sedikit sulit dikendalikan, belum lebih dari setengah jumlah siswa di kelas antusias dalam pembelajaran. Selain itu, pengamat melihat kurangnya kemampuan siswa dalam memecahkan masalah yang terkait dengan konsep yang dipelajari, kurang terjadi interaksi antara siswa dan guru, serta siswa kurang dapat merefleksikan kegiatan yang telah dilaksanakan untuk memperbaiki kesalahan.

\section{Siklus II}

1. Hasil tindakan penelitian

Berdasarkan tindakan penelitian siklus II mengenai proses pembelajaran Matematika tentang nilai tempat dengan mengefektifkan alat bantu di kelas III maka hasil yang didapat untuk rata-rata hasil tes evaluasi belajar siswa adalah 67 dan pencapaian nilai enam sampai dengan sepuluh baru mencapai $63,3 \%$

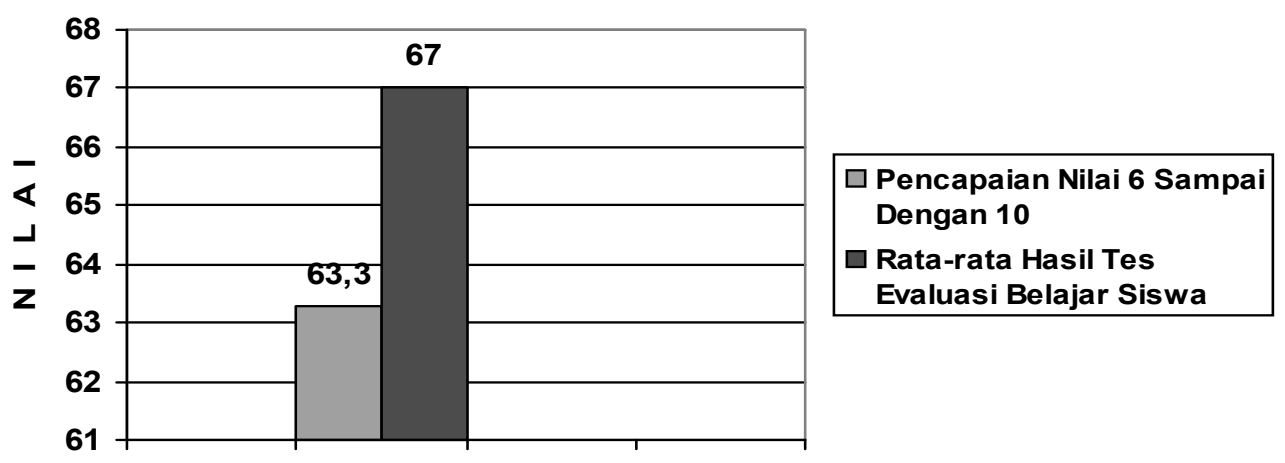

Gambar 3. Siklus II

\section{Hasil pengamatan tindakan}

Dari hasil pengamatan yang dilakukan oleh pengamat terhadap pelaksanaan tindakan pembelajaran yang dilaksanakan oleh peneliti pada siklus II, diperoleh rata-rata persentase terhadap observasi sikap guru saat membelajarkan dan observasi terhadap suasana kelas yang di dalamnya tergambar aktivitas siswa saat pembelajaran sebesar $71 \%$. Berikut digambarkan pengalaman tindakan sebagai berikut.

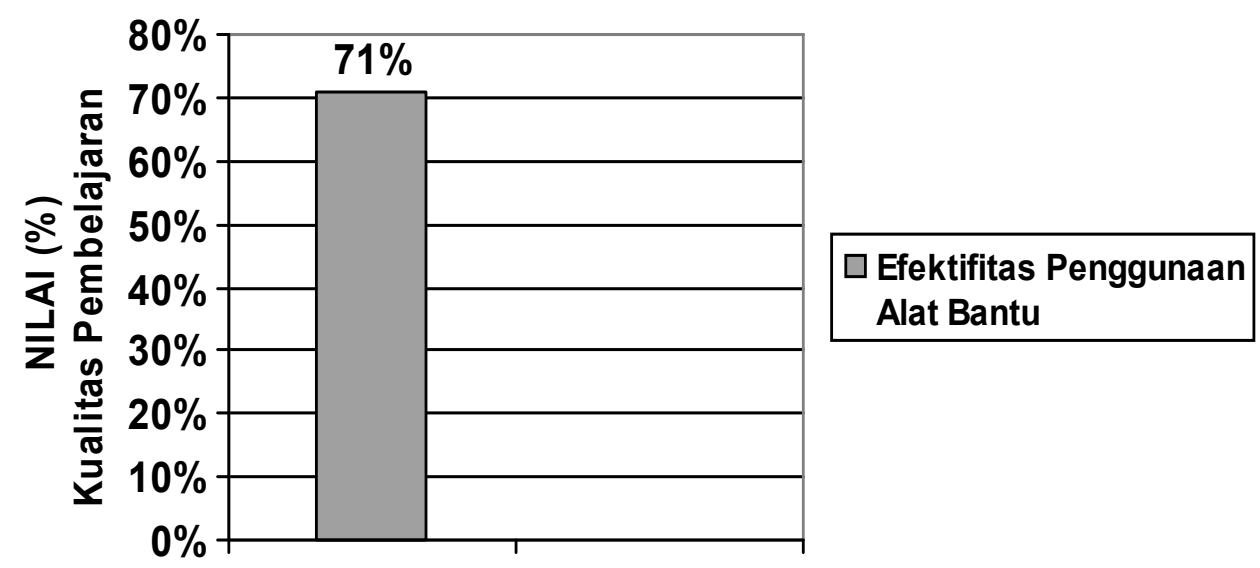

\section{Efektifitas Penggunaan Alat Bantu}

Gambar 4. Pengamatan tindakan siklus II 


\section{Refleksi tindakan}

Berdasarkan hasil intervensi tindakan yang sudah dilaksanakan oleh peneliti dalam melakukan tindakan pembelajaran Matematika tentang nilai tempat dengan mengefektifkan alat bantu di kelas III, hasil rata-rata 63,3 untuk latihan dan $71 \%$ untuk proses pembelajaran yang meliputi, aktivitas guru dan suasana kelas yang menggambarkan aktivitas siswa dalam pembelajaran tersebut sudah meningkat namun masih terlihat adanya kekurangan-kekurangan guru, misalnya kurangnya motivasi guru untuk memperbaiki kesalahan, kurangnya penguatan dari guru dalam menumbuhkan rasa percaya diri siswa dan saat pembelajaran, guru kurang menciptakan suasana yang menimbulkan inisiatif dan kreativitas siswa sehingga timbul ketidakpuasan siswa dalam menemukan konsep.

Selain itu, berdasarkan catatan lapangan dan diskusi dengan pengamat terlihat kondisi siswa sedikit sulit dikendalikan. Hal ini terlihat dari tidak lebih dari setengah jumlah siswa di kelas antusias dalam pembelajaran. Pengamat melihat kurangnya kemampuan siswa dalam memecahkan masalah yang terkait dengan konsep yang dipelajari, kurang terjadi interaksi antara siswa dengan guru, dan siswa kurang dapat merefleksikan kegiatan yang telah dilaksanakan guna memperbaiki kesalahan. Berdasarkan uraian di atas maka peneliti dan pengamat memutuskan untuk membuat rencana tindakan pembelajaran siklus III.

\section{Siklus III}

1. Hasil tindakan penelitian

Berdasarkan tindakan penelitian siklus III dalam proses pembelajaran Matematika tentang nilai tempat dengan mengefektifkan alat bantu di kelas III maka hasil yang didapat untuk rata-rata hasil tes evaluasi belajar siswa adalah 75 dan pencapaian nilai enam sampai dengan sepuluh baru mencapai 95\%.

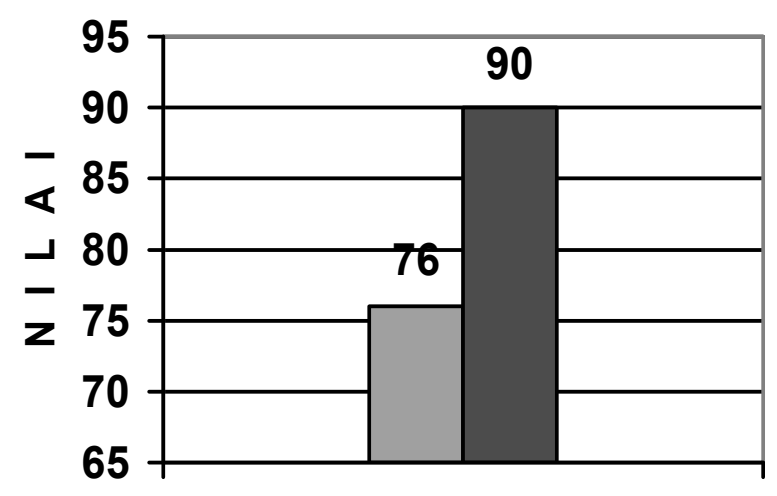

\begin{tabular}{|c|}
\hline$\square$ Rata-rata Hasil Tes \\
Evaluasi Belajar \\
$\square$ Pencapaian Nilai 6 \\
Sampai Dengan 10 \\
\hline
\end{tabular}

Gambar 5. Siklus III

2. Hasil pengamatan tindakan

Dari hasil pengamatan yang dilakukan oleh pengamat terhadap pelaksanaan tindakan pembelajaran yang dilaksanakan oleh peneliti pada siklus
III, diperoleh rata-rata persentase terhadap observasi sikap guru saat membelajarkan dan observasi terhadap suasana kelas yang di dalamnya tergambar aktivitas siswa saat pembelajaran sebesar $84 \%$.

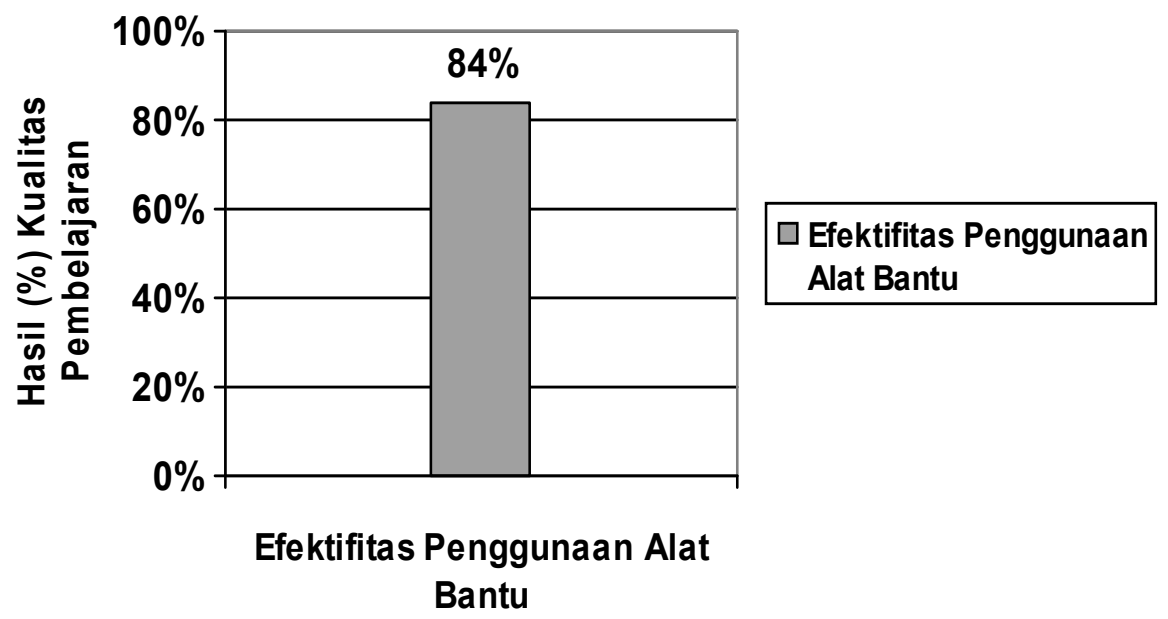

Gambar 6. Pengamatan tindakan siklus III 


\section{Refleksi tindakan}

Intervensi tindakan yang sudah dilaksanakan oleh peneliti melalui tindakan pembelajaran tentang nilai tempat sampai dengan ribuan pada siklus III menunjukkan adanya peningkatan. Hal ini dapat terlihat melalui pencapaian nilai rata-rata siswa dalam latihan sebesar 90 dan tindakan guru yang dilakukan dalam proses pembelajaran mencapai $84 \%$. Pada siklus III sudah terlihat suasana pembelajaran yang mengefektifkan alat bantu, kegiatan pembelajaran sudah didominasi oleh siswa sehingga kesempatan memiliki pengalaman belajar menjadi lebih banyak, terjadi interaksi antara siswa dengan siswa, siswa dengan guru, serta kemandirian siswa dalam melaksanakan aktivitas pembelajaran.

Semua yang dilakukan oleh guru dan siswa dalam pembelajaran melalui mengefektifkan alat bantu sudah memenuhi standar keberhasilan yang di terapkan peneliti. Melihat hasil yang didapat pada siklus I, II, dan III yang telah menunjukkan adanya grafik peningkatan maka peneliti memutuskan untuk mengakhiri tindakan pembelajaran.

\section{Pembahasan}

Berdasarkan hasil data yang diperoleh pada tindakan pembelajaran Matematika dengan mengefektifkan alat bantu telah menunjukkan adanya peningkatan pada kualitas pembelajaran yang terlihat pada pencapaian hasil belajar siswa dan tindakan pembelajaran yang dilakukan guru, yaitu siklus I = 50 untuk rata-rata nilai latihan dan $60 \%$ untuk tindakan pembelajaran, siklus II $=63,3$ untuk rata-rata nilai latihan dan $71 \%$ untuk tindakan pembelajaran serta di siklus III = 90 untuk rata-rata nilai latihan dan $64 \%$ untuk tindakan pembelajaran. Melihat hasil yang dicapai tersebut membuktikan bahwa pendekatan pembelajaran dapat digunakan guru untuk meningkatkan kualitas pembelajaran Matematika di SD.

Dari gambar siklus I, II, dan III dapat dikatakan bahwa pada siklus I proses pembelajaran masih dipengaruhi oleh sikap guru yang kurang terbuka, tegang, dan kurang memberi penguatan sehingga mempengaruhi sikap siswa dalam pembelajaran. Situasi pembelajaran juga kurang menyenangkan dan dengan kondisi tersebut kurang dapat mengembangkan keaktifan siswa yang berdampak pada baiknya pemahaman konsep mereka.

Pada siklus III guru sudah lebih terlatih dalam melaksanakan pembelajaran dengan mengefektifkan alat bantu maka ketegangan dan kekhawatiran akan tidak tersampaikannya target pembelajaran sudah berkurang. Suasana pembelajaran sudah lebih hidup. Pada siklus III ini sudah menggambarkan prinsip- prinsip serta karakteristik tentang alat bantu. Ketika guru sudah dapat bersikap lebih terbuka, memberi keluasan dan kepercayaan penuh pada siswa maka siswa pun ternyata lebih yakin akan potensi dirinya sehingga mampu menggali dan mengembangkannya. Siswa dapat menemukan konsep dengan mandiri, dapat menyelesaikan masalah, dan dapat menerapkan konsep yang dipelajari dalam kehidupan mereka sehari-hari. Implementasi dari pendekatan tersebut tidak lepas dari upaya guru dalam mengembangkan inovasi dan kreativitas dalam merumuskan rancangan dan proses pembelajaran dengan mengefektifkan alat bantu tersebut.

\section{KESIMPULAN}

\section{Kesimpulan}

Hasil penelitian memperlihatkan pembelajaran Matematika tentang nilai tempat dengan mengefektifkan alat bantu, mampu melibatkan kemampuan sosial, emosional, dan intelektual siswa secara terpadu sehingga dapat memunculkan potensi siswa, merangsang berpikir analisis, dan mampu belajar memecahkan masalah sendiri. Selain itu, siswa lebih menikmati dan mengikuti pembelajaran dengan antusias serta rasa sayang sehingga pemahaman konsep siswa tentang nilai tempat yang didapat siswa lebih baik. Hal ini ditimbulkan dengan penelitian yang telah dilakukan aktivitas siswa yang tergambar 7,6 dan suasana kelas ketika guru beraktivitas sebesar $84 \%$, artinya lebih dari sebagian siswa beraktivitas dalam pembelajaran sudah dapat memperlihatkan peningkatan pemahaman konsep Matematika siswa. Siswa yang telah mendapatkan pemahaman yang baik ternyata dapat menjadi tutor sebaya untuk temannya yang lain sehingga dapat membantu meningkatkan pemahaman konsep Matematika. Terlebih bila aktivitas siswa dalam pembelajaran mencapai lebih dari 75\% maka kualitas pembelajaran Matematika tentang nilai tempat akan meningkat lagi.

\section{Implikasi}

Pengefektifan alat bantu dapat meningkatkan kualitas pembelajaran Matematika siswa kelas III SD. Dengan mengaktifkan alat bantu siswa berkesempatan untuk berpikir logis, memiliki sifat kerja sama yang baik dalam kelompok, dan memiliki rasa percaya diri. Dengan kemampuan-kemampuan yang dimiliki siswa dapat menyelesaikan masalah operasi hitung tentang tempat dalam kehidupan sehari-hari.

\section{Saran}

Hasil yang diperoleh pada kesimpulan penelitian memperhatikan salah satu cara yang tepat untuk 
melihat atau mengetahui secara langsung kekurangan baik siswa maupun guru yang membelajarkan. Oleh karena itu, peneliti menyarankan sebagai berikut.

1. Anak didik, diharapkan lebih sering mengefektifkan alat bantu dalam pembelajaran karena sesuai dengan karakteristik siswa SD.

2. Pendidik, diharapkan terus memperbaiki kinerja dengan mengembangkan kreativitas guru dalam merancang pembelajaran.

3. Kepala Sekolah, agar dapat memberi dukungan dan bimbingan kepada guru untuk dapat menerapkan pembelajaran yang aktif.

4. Instansi dan Pemerintah, agar memberi dukungan melalui penyediaan sarana dan prasarana pendidikan sesuai dengan kebutuhan di lapangan

5. Mahasiswa dan pembaca umumnya, dapat menindaklanjuti karya ilmiah ini dengan melakukan penelitian lebih lanjut sehingga dapat diperoleh data yang lebih akurat.

\section{DAFTAR PUSTAKA}

Angkowo, R. \& Kosasih, A. (2007). Optimalisasi media pembelajaran. Jakarta: Grasindo.

Arikunto, S. (1996). Dasar-dasar evaluasi pendidikan. Jakarta: Bumi Aksara

Departemen Pendidikan dan Kebudayaan. (1994). Petunjuk pembelajaran berhitung. Jakarta: Depdikbud.

Dimyati \& Mudjiono. (2006). Belajar dan pembelajaran. Jakarta: Rineka Cipta.

Horn, J.V. (1993). Play at the centre of the curriculum. New York: Mac Millan Publishing Company.
Mulyasa, E. (2005). Menjadi guru profesional menciptakan pembelajaran kreatif dan menyenangkan. Bandung: Remaja Resada.

National Council of Teachers of Mathematics (NCTM). (1973). Instructional aid in mathematics. New York: Macmillan.

Paimin, J. E. (2007). Agar anak pintar matematika. Surabaya: ITS.

Souveniy, R.J. (1993). Learning to teachs mathematics. USA: USA \& CO.

Subarinah, S. Inovasi pembelajaran matematika sekolah dasar. (2006). Jakarta: Depdiknas.

Sumantri, Mulyani, \& Permana, J. (1999). Strategi belajar mengajar 1998/1999. Jakarta: Depdikbud.

Suparno, P. (2000). Teori perkembangan kognitif Jean Piaget. Yogyakarta: Kanisius.

Sutikno, M. S. (2007). Menggagas pembelajaran efektif dan bermakna. Mataram: NTP Pres.

Tim Dosen PTK. (2006). Konsep dasar dan karakteristik penelitian tindakan kelas. Jakarta: Pendidikan Guru Sekolah Dasar, Universitas Negeri Jakarta.

Wiraatmadja, R. (2005). Metode penelitian tindakan kelas. Bandung: Remaja Rosda Karya.

\section{KETERANGAN PENULIS}

F.T. Munthe, dilahirkan di Karo, November 1945. Saat ini menjabat sebagai dosen Jurusan Pendidikan Guru Sekolah Dasar FIP UNJ. Karya ilmiah terbaru yang diselesaikan adalah Accelerated Learning for $21^{\text {st }}$ Century pada tahun 1998. 